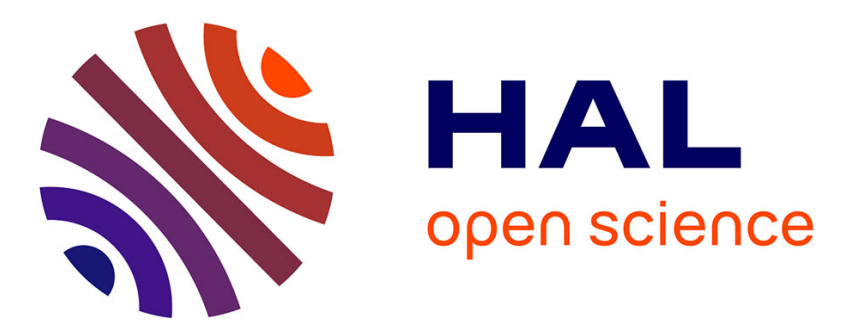

\title{
Parental body size and early weight and height growth velocities in their offspring.
}

Jérémie Botton, Barbara Heude, Jean Maccario, Jean-Michel Borys, Agnes

Lommez, Pierre Ducimetière, Marie-Aline Charles

\section{To cite this version:}

Jérémie Botton, Barbara Heude, Jean Maccario, Jean-Michel Borys, Agnes Lommez, et al.. Parental body size and early weight and height growth velocities in their offspring.. Early Human Development, 2010, 86 (7), pp.445-50. 10.1016/j.earlhumdev.2010.06.001 . inserm-00555060

\section{HAL Id: inserm-00555060 https://www.hal.inserm.fr/inserm-00555060}

Submitted on 12 Jan 2011

HAL is a multi-disciplinary open access archive for the deposit and dissemination of scientific research documents, whether they are published or not. The documents may come from teaching and research institutions in France or abroad, or from public or private research centers.
L'archive ouverte pluridisciplinaire HAL, est destinée au dépôt et à la diffusion de documents scientifiques de niveau recherche, publiés ou non, émanant des établissements d'enseignement et de recherche français ou étrangers, des laboratoires publics ou privés. 


\section{Parental body size and early weight and height growth velocities in their offspring.}

Jérémie Botton (1,2), Barbara Heude (1,2), Jean Maccario (3), Jean-Michel Borys (4), Agnes Lommez (4), Pierre Ducimetière $(3,5)$, Marie Aline Charles $(1,2)$ and the FLVS study group (4)

(1) Epidemiology of diabetes, obesity and chronic kidney disease over the

lifecourse, CESP Centre for research in Epidemiology and Population Health, U1018, Inserm, F-94807, Villejuif, France

(2) Université Paris Sud 11, UMRS 1018, F-94807, Villejuif, France

(3) Université Paris Descartes 5, F-75006 Paris, France

(4) Fleurbaix Laventie Ville Santé Association, F-62840 Laventie, France

(5) Cardiovascular Epidemiology and Sudden Death, U909, Inserm, F-75908 Paris, France

\section{Corresponding author:}

Jérémie Botton

16 avenue Paul Vaillant Couturier, F-94807 Villejuif Cedex, France

Tel/Fax: (+33) 145596052 / (+33) 147269454

e-mail: jeremie.botton@inserm.fr

Abbreviations: BMI (Body Mass Index), FLVS (Fleurbaix Laventie Ville Santé), SD

(Standard Deviation), CI (Confidence Interval)

Key terms: development and growth, epidemiology, parental BMI and height 


\section{Abstract}

Background: Whereas weight or height at a given age are the results of the cumulative growth experience, growth velocities allows the study of factors affecting growth at given ages. Aim: to study the relationships between parental height and body mass index (BMI) and offspring's height and weight growths during infancy and childhood. Study design: From the FLVSII population-based study, 235 parent-child trios belonging to 162 families examined in 1999. Outcome measures: From medical records and previous FLVS examinations, child's height and weight history was reconstructed. Weight and height growth velocities from birth to seven years were estimated from a modelling of individual growth curve and correlated with parent's body size in 1999. Results: Ponderal index and length at birth was significantly associated with maternal but not paternal BMI and height. In the first six months, height growth velocity was significantly associated with maternal stature (at three months: $0.12 \pm 0.05$ and $0.02 \pm 0.05 \mathrm{~cm} / \mathrm{mo}$ for a $10 \mathrm{~cm}$ difference in maternal and paternal height respectively) and weight growth velocity with paternal BMI (at three months: 5.7 \pm 2.8 and $1.9 \pm 2.3 \mathrm{~g} / \mathrm{mo}$ for a difference of $1 \mathrm{~kg} / \mathrm{m}^{2}$ in paternal and maternal BMI respectively). Between two and five years, height growth velocity was more significantly associated with paternal height whereas weight growth velocity was more closely associated with maternal BMI.

Conclusions: Early childhood growth is characterised by alternate periods associated specifically with maternal or paternal BMI and height. This novel finding should trigger the search for specific genetic, epigenetic or environmentally shared factors from the mothers and fathers. 


\section{Introduction}

There is emerging evidence for periods during infancy and childhood during which children are more susceptible to develop fat mass $[1,2]$. We recently reported results supporting the hypothesis of two critical windows in early childhood associated with an increased risk of obesity in adolescence: the first six months and from three to at least five years [2]. From six months to three years, weight growth velocity was only associated with height in adolescence.

Determinants of weight and height growth specific to these periods need to be studied. A determinant consistently associated with children's weight and body mass index (BMI) is parental BMI. It is therefore of interest to assess how parent-child associations develop during different periods. Researchers have been interested for a long time in the relationships between parental characteristics and weight during the offspring's early life. In a study published in 1954, weight at birth and in early infancy were more correlated with maternal than paternal stature, but this difference disappeared before adulthood [3].

More recently, many studies have reported the relationships between maternal and sometimes paternal BMI with the offspring's BMI at birth or older ages: 3 years [4]; 7.5 years [5]; 9 years [6]. They concluded that there was a positive association between mother's and offspring's BMIs; there were differing results about the relationship with the father's BMI. Anthropometric relationships between parents and children throughout childhood have been reported in the FLVS study [7]: BMI at birth was highly correlated with the mother's but not the father's BMI; correlations between offspring's and father's BMI were significant at two years.

To our knowledge, few studies have reported relationships between parental anthropometry and weight growth during infancy and childhood [8,9], and none considered both height and 
weight growth. The velocities allow to study factors affecting growth at given ages, whereas weight and height are the result of the prenatal and postnatal cumulative growth experience.

We aimed at studying the relationships between parents' BMI and height with both their offspring's weight and height growth velocities between birth and seven years.

\section{Population and Methods}

The subjects were recruited in Fleurbaix and Laventie, two neighbouring towns in northern France, with respectively 2488 and 4426 inhabitants in 1992, when the Fleurbaix-Laventie Ville Santé (FLVS) study started. The first part of the study (FLVS I), was a five-year followup of children participating in a nutritional education program at school and included 579 families [10].

The second part (FLVS II) was an epidemiological study on the determinants of weight change in the population. This study was proposed to the families who participated in the FLVS I study. Written consent was obtained from children and parents. The study was approved by the ethics committee of Lille (France) and the computer files were declared to the "Commission Nationale Informatique et Liberté". We recruited and examined, between April and September 1999, 294 of the 393 families still living in these towns that could be contacted. All family members aged 8 years and over were examined at home in 1999 (1113 individuals). In this analysis, we included 235 parent-child trios belonging to 162 families with available data on parents' BMI and children anthropometry (weight and length or height at birth, nine months, two years and weight and height growth velocities). Other trios were not included because for 180 children the number of measurements during childhood failed to meet the requirement for growth modelling (see below). Among the other trios, paternal measurements were missing for 55, maternal for 4 and offspring's at birth, nine or two years for 41. 
In offspring, weight and height from birth until twelve years were available from the "Carnet de santé", a booklet for parents and health practitioners recording the child's health data (precision of the measurements unknown), and as part of the longitudinal follow-up of the children in the FLVS I and II studies since the children were between five and twelve years (weight was measured in light clothes to the nearest $0.1 \mathrm{~kg}$ and height to the nearest $\mathrm{cm}$ ). We calculated the ponderal index at birth as weight in kg over cubic length in meters, and BMI at nine months and two years as weight in kg over square height in meter. These indices are generally uncorrelated to length or height (confirmed in our data set).

In parents, anthropometric data were collected in 1999 by trained physicians during the FLVS II study. Weight was measured in light clothes to the nearest $0.1 \mathrm{~kg}$, height to the nearest $\mathrm{cm}$ and BMI calculated.

\section{Statistical analysis}

We first estimated the weight and height growth velocities (a). Then, we used these velocities in models to test if there were differences between parents, and according to time (b).

a. Weight and height growth velocities estimation

The methodology used to estimate weight and height growth velocities has been described in detail elsewhere [2]. Measurements of weight and height from birth to twelve years allowed us modelling each child's growth individually, using an adaptation of the Jenss growth curve model [11] by adding a squared-time coefficient:

$y_{i}(t)=a_{i}+b_{i} t+c_{i} t^{2}-\exp \left(d_{i}+e_{i} t\right)+\varepsilon_{i}$, where $\mathrm{y}_{\mathrm{i}}$ is the weight of the child $i$ at age $t, \varepsilon_{i}$ being the residual. The same model was found to also fit the height growth.

The least-squares estimates were determined for each child using the SAS PROC NLIN. We included children with at least six measures available between birth and twelve years, two 
before two years and one after five years. The first derivative of the equation of the individual models calculated at selected age $(0.25,0.5,1,2,3,4,5$ and 7 years $)$ gave the respective growth velocities.

b. Descriptive and aetiological analyses

General characteristics are given as means (SD) or geometric means [CI] for the parents' BMI. Differences between mother's and father's characteristics were tested using paired ttests. For children, all between gender comparisons used mixed effect models to take into account the family resemblance between brothers and sisters.

We estimated the relative contribution of each parent's height or BMI to the offspring's growth velocities by a multiple regression model at each selected age, including the parameter of both parents. The models took into account the family resemblance by introducing a random intercept and were additionally adjusted for mother's age, child's gender, and gestational age when parameter was measured at birth.. We also tested whether the differential effect of parental measures at these selected age (age-dependence) was significant, by testing the interaction term between parent's measures and age in a mixed model for longitudinal data: the variance-covariance structure which best fitted our data was an autoregressive heterogeneous one.

Differences in relationships between boys and girls were tested by including in the models an interaction term with offspring's gender. Finally, differences between father's and mother's contributions were tested by comparing the corresponding regression coefficients by a Wald test.

BMI being independent of height at the population level, we reported the relationships with parents' BMI rather than parents' weight. 
Significance tests were two-sided and a p-value greater than 0.05 noted as non significant. We used SAS Software version 9.1.

\section{Results}

None of the anthropometric parameters of the 1999 FLVS II examination was significantly different in our study population between children included or not in the present analysis.

\section{General characteristics (table 1)}

In the 162 families, fathers had as expected higher weight, height and BMI than mothers. The 122 male offspring had a mean birth weight of $3.39 \mathrm{~kg} \pm 0.53$ versus $3.35 \mathrm{~kg} \pm 0.52$ for the 113 girls $(\mathrm{p}=0.14)$, and a mean birth length of $50.3 \mathrm{~cm} \pm 2.3$ versus $49.7 \mathrm{~cm} \pm 2.3$ in girls $(\mathrm{p}=0.003)$. The mean weight and height growth velocities at given ages during infancy and childhood are presented in figures $1 \mathrm{~A}$ and $1 B$. Boys gained $0.67 \pm 0.16 \mathrm{~kg} / \mathrm{mo}$ at three months compared to $0.65 \pm 0.13 \mathrm{~kg} / \mathrm{mo}$ for girls $(\mathrm{p}=0.17)$. Three months height growth velocity was significantly greater in boys $(\mathrm{p}=0.02)$. After three months, there were no significant differences in height and weight growth velocities between boys and girls.

\section{Parent's BMI: relationship with offspring's BMI and weight growth velocities} (figure 2)

Parent's BMI was not significantly associated with either the offspring's height or height growth velocities (results not shown). Thus, the associations described above between parent's BMI and the offspring's weight growth are unlikely attributable to the offspring's height growth.

Offspring's BMI as endpoint. Mother's BMI was significantly associated with ponderal index at birth (figure 2A). A difference of $1 \mathrm{~kg} / \mathrm{m}^{2}$ in mother's and father's BMI was 
associated with a difference in ponderal index of $0.097 \pm 0.04 \mathrm{~kg} / \mathrm{m}^{3}(\mathrm{p}=0.01)$ and $0.046 \pm$ $0.05 \mathrm{~kg} / \mathrm{m}^{3}(\mathrm{p}=0.34)$ respectively. Both parental BMIs were associated with the offspring's BMI at nine months (difference of $0.055 \pm 0.03 \mathrm{~kg} / \mathrm{m}^{2}$ and $0.069 \pm 0.03 \mathrm{~kg} / \mathrm{m}^{2}$ in the child's BMI per $\mathrm{kg} / \mathrm{m}^{2}$ in the mother's $(\mathrm{p}=0.04)$ and father's BMI $(\mathrm{p}=0.04)$ respectively).

Offspring weight growth velocity as endpoint. Offspring weight growth velocity at three months was more strongly associated with the father's BMI (figure $2 \mathrm{~B}: 5.7 \pm 2.8 \mathrm{~g} / \mathrm{mo}$ per $\mathrm{kg} / \mathrm{m}^{2}$ in father's BMI and $1.9 \pm 2.3 \mathrm{~g} / \mathrm{mo}$ per $\mathrm{kg} / \mathrm{m}^{2}$ in mother's BMI). Between six months and three years, parental BMIs were not associated with the offspring's weight growth velocity. At older ages, both parental contributions increased, more rapidly for the maternal contribution. These associations between father's or mother's BMI and offspring weight growth velocity were age-dependant (p-for-interaction with age $=0.08$ and 0.001 respectively). Although interaction with offspring's gender was not significant, we observed that from three years onward, maternal contribution seemed preponderant in girls (supplementary figures). At seven years, the difference of the contributions between the two parents reached $2.9 \pm 2.3$ $\mathrm{g} / \mathrm{mo}$ for $1 \mathrm{~kg} / \mathrm{m}^{2}(\mathrm{p}=0.22)$ in girls and $0.13 \pm 2.2 \mathrm{~g} / \mathrm{mo}$ for $1 \mathrm{~kg} / \mathrm{m}^{2}(\mathrm{p}=0.95)$ in boys.

\section{Parental stature: relationship with offspring's height and height growth velocities} (figure 3)

Offspring's length as endpoint. The offspring's birth length and height during infancy and childhood were significantly and positively associated with the mother's height over the whole period and with the father's height only at two years (figure 3A). At nine months, the test for a difference between maternal and paternal contribution was close to significance $(\mathrm{p}=0.08)$.

Offspring height growth velocity as endpoint. The mother's height was more strongly associated with the offspring's height growth velocity in the first six months of life than father's height (figure 3B: $0.12 \pm 0.05 \mathrm{~cm} / \mathrm{mo}$ at three months for a $10 \mathrm{~cm}$ difference in 
mother's height and $0.02 \pm 0.05 \mathrm{~cm} / \mathrm{mo}$ for $10 \mathrm{~cm}$ difference in father's height). At one year, the height growth velocity was not associated with parental stature. From two to five years, height growth was strongly associated with the father's height, whereas significant associations with the mother's height reappeared at four years and its effect remained much smaller than those with father's height (p-for-difference in contributions at three and four years $=0.02$ and 0.08 respectively). These associations between father's or mother's height and height growth velocity were age-dependant ( $\mathrm{p}$-for-interaction with age $=0.13$ and 0.02 respectively). In girls, at seven years the contribution of maternal height re-increases, becomes significantly higher than paternal contribution (supplementary figures) and significantly higher than in boys ( $\mathrm{p}$ for interaction with offspring's gender $=0.006$ ).

\section{Discussion}

Height and ponderal index at birth were significantly associated with maternal but not paternal height and BMI. In the first six months of life, height growth velocity was associated with maternal stature and weight growth velocity with paternal BMI. Between two and five years, the reverse was observed: height growth velocity was more significantly associated with paternal height whereas weight growth velocity was more closely associated with maternal BMI.

Many authors highlighted the importance of parental determinants in the height and weight of their offspring [3, 12-14]. Height and weight mirror multiple convergent genetic, environmental and hormonal interactions. However, it is currently admitted that height is mainly determined by genetic aspects in the absence of prolonged deficit in energy intake [15, 16]. Weight might be less heritable than height, even if genetic factors are probably still preponderant during at least infancy and childhood [17]. 
The mother's contribution to the offspring's length at birth probably reflects both genetic factors and the intra-uterine constraint. After birth, it is thought that the height growth velocity adjusts towards a genetically predicted trajectory [18]. However, our data show that the parental influences on the offspring's postnatal height growth seem to follow a differential pattern over time. There were stronger associations between the mother's height and the child's height growth velocity in the first months of life and stronger associations with the father's height after two years. If one admits that genes account for most of these associations, these mirroring patterns could reveal an underlying biological mechanism in growth regulation involving an alternating influence of maternal and paternal genes. Imprinting is well demonstrated in genes involved in the control of growth [19] and offers a potential mechanism behind our findings. For example, over-expression of paternal alleles in the IGF2 gene in Beckwith-Wiedemann syndrome which results in a marked acceleration of bone growth in infancy and early childhood [20] is in accordance with the stronger association between height growth velocity with father's than mother's height after two years in our results. A shared environment hypothesis (food intake, physical activity) between parents and offspring, enhancing the offspring's height growth during specific periods is less plausible.

The known relationship between offspring's ponderal index at birth and maternal but not paternal BMI is in accordance with the hypothesis of a preponderant impact of the maternal intra-uterine environment on fetal weight growth. The nutritional status of the mother before and during pregnancy, her metabolism and her dietary intake during pregnancy will determine the amount of glucose, oxygen and other nutrients the foetus will receive via the placenta [21, 22].

In this context, genetic traits for weight growth, inherited from the mother or the father, may show up more frankly after birth $[21,23]$. In our study, paternal BMI was correlated with the 
offspring's early postnatal weight growth contrasting with the absence of association with birthweight. These relationships had already been highlighted in distinct studies $[9,24,25]$ Consequently, paternal and maternal contributions to the offspring's BMI was similar at nine months. Unlike the study from Griffiths et al [9], the mother's BMI did not significantly contribute to the child weight growth velocity in the first three years of life. Our results concur with the observation that the relationship between body weight of mothers and their offspring's weight is weaker during the first two years of life than at birth [26]. The postnatal preponderant influences of the fathers' BMI would unlikely be explained by environmental factors shared with the offspring during early infancy, but rather by paternal genes, which could not be expressed in utero for reasons such as maternal constraint or because they influence food intake behaviour. An interesting hypothesis has been advanced from the studies of human disorders of imprinted genes suggesting that alleles of paternal origin, expressed in infants, have been selected to favor more intense suckling than those of maternal origin [20]. In particular, children with Prader-Willi syndrome - caused by defect of a paternally expressed allele - experience a poor suck and failure to thrive in infancy. Therefore alleles of paternal origin may have a specific effect on offspring growth during the suckling periods which fits well with our observation of preferential association with paternal than maternal BMI in the fist months of life.

Maternal BMI was associated with the child's weight growth velocity from three years onwards. It is tempting to speculate that there is an increasing influence of shared environment and behaviours from three years onward. It has been shown that parents play a role in the eating behaviour of their offspring [27]. Preferences for a fatty diet have been related to parental adiposity [28]. One could expect a preponderant role of the mothers, who usually spend more time with their children than fathers in shaping the eating behaviour of their child. However, a stronger association of the offspring's BMI or weight growth rate with 
the mother's BMI compared to the father's BMI is not consistently found [4]. Such discrepancies might be dependant on the relative involvement (eg time spent) of the father compared to the mother across the studies, and on the offspring's gender. In our study, the contribution of the mother's BMI was significantly higher in girls than in boys.

Our results about the association between parental BMI and the child's weight growth velocity can also be considered in the context of our previous finding of two periods where weight growth velocity predicts fat mass in adolescence [2]. The first period - the first six months of life - is more related to paternal BMI, which suggests a role for genetic factors. The second period - from three years onwards - is related to both parents' BMI. It is noteworthy that during the intermediate period where growth velocity was not related to fat mass in adolescence, there was also no significant contribution of the parents' BMI.

A first limitation of our study is that parental measurements were performed during the FLVS II study in 1999, when the offspring was already 8-17 years old. However, there is a high tracking of BMI during adulthood. Adjusting for the offspring's age at the date of parental measurements did not change the results. Obviously, this limitation does not concern relationships with height which, given the parents' age, should not change between their child's birth and the examination. Secondly, our sample, while being large enough to highlight relationships between parental and child characteristics, may not be powerful enough to highlight all differences between the mother-child and the father-child relationships, nor interactions with offspring's gender. However, stratification by gender allowed us to point out the significantly stronger contributions of the mother than the father to their daughter's weight and height growth velocities from five years onwards. Thirdly, we did not have data to test for a difference of the parental contributions according to whether the children were breastfed or not. 
A first strength is the quality of the parental data, measured by trained clinicians, whereas other epidemiological studies often use reported data, particularly for the fathers. Secondly, the growth model allowed us to study the dynamic aspect of the relationships between parents' and children's characteristics: whereas measurements at given ages reflect the cumulative past growth experience, including the prenatal period, weight and height growth velocities are instantaneous estimates at given time points and enable identification of effects at specific periods.

In conclusion, we have shown successive periods from birth to seven years, during which the growth in weight and height have preferential and successive associations with either paternal or maternal body size. It is tempting to parallel this finding with the current knowledge on growth physiology in infancy, where growth hormone independent stimuli control growth in prenatal and early postnatal life, followed by a take-over by growth hormone dependent mechanisms [18]. The recent hypotheses raised from the analysis of human disorders of imprinted genes offers another conceptual framework for the interpretation of our results [20]. Our results should trigger the search for specific genetic, epigenetic or shared environmental factors from the mother and the father that influence childhood growth and thus have major implications for further studies of height and weight growth regulation, including genetic studies. 


\section{FIGURE LEGENDS:}

1A: Mean weight growth velocities (and SD) in boys and girls at different ages between birth and seven years.

1B: Mean height growth velocities (and SD) in boys and girls at different ages between birth and seven years.

2A: Coefficients of a multiple regression model for each age (and 95\% confidence intervals) corresponding to the increase in offspring's ponderal index at birth or BMI at nine months and two years for a $1 \mathrm{~kg} / \mathrm{m}^{2}$ increase in father's or mother's BMI. Models included parent's BMIs, mother's age, offspring's gender, gestational age when model included birth measurements and took into account the family resemblance.

2B: Coefficients of a regression model for each selected age (and 95\% confidence intervals) corresponding to the increase in offspring's weight growth velocity at different ages between 3 months and 7 years for a $1 \mathrm{~kg} / \mathrm{m}^{2}$ increase of in father's or mother's BMI. Models included parent's BMIs, mother's age, offspring's gender and took into account the family resemblance.

3A: Coefficients of a multiple regression model for each age (and 95\% confidence intervals) corresponding to the increase in offspring's length at birth, nine months and 2 years for a 10 cm increase in father's or mother's height. Models included parent's heights, mother's age, offspring's gender, gestational age when model included birth parameters and took into account the family resemblance.

3B: Coefficients of a multiple regression model for each age (and 95\% confidence intervals) corresponding to the increase in offspring's height growth velocity at different ages between 3 months and 7 years for a $10 \mathrm{~cm}$ increase in father's or mother's height. Models included parent's heights, mother's age, offspring's gender and took into account the family resemblance. 


\section{Acknowledgment:}

We thank directors and teachers of the schools who made the study possible. We thank the parents and their children who agreed to participate in the study.

We also thanks Pr Yves Le Bouc, Dr S Cabrol, Dr I Netchine, INSERM unit 535 and Hôpital Armand Trousseau for their helpful comments on our results.

Members of the Fleurbaix Laventie Ville Santé Group: Arnaud Basdevant, Jean-Michel Borys, Jean-Louis Bresson, Marie-Aline Charles, Pierre Ducimetière, Philippe Froguel, Barbara Heude, Agnes Lommez, Jean-Michel Oppert, Monique Romon.

Marie-Aline Charles received grants from the “Association de Langue Française pour l'étude des diabètes et du metabolisme", ALFEDIAM; the "Mutuelle Generale de l'Education Nationale", MGEN; and the study was supported by Laboratoires Knoll, CEDUS, Groupe Fournier, Lesieur, Nestlé France, Produits Roche and TEPRAL. The study sponsors had no role in the study design, in the collection analysis and interpretation of data; in the writing of the manuscript, and in the decision to submit the manuscript for publication.

Conflict of interest statement: I fully declare any financial or other potential conflict of interest 


\section{References}

[1] Ekelund U, Ong KK, Linné Y, Neovius M, Brage S, Dunger DB, Wareham NJ, Rössner S. Association of weight gain in infancy and early childhood with metabolic risk in young adults. J Clin Endocrinol Metab 2007;92:98-103.

[2] Botton J, Heude B, Maccario J, Ducimetière P, Charles MA, FLVS study group. Postnatal weight and height growth velocities at different ages between birth and $5 \mathrm{y}$ and body composition in adolescent boys and girls. Am J Clin Nutr 2008;87:17601768

[3] Cawley RH, McKeown T, Record RG. Parental stature and birth weight. Am J Hum Genet 1954;6:448-456.

[4] Whitaker RC, Deeks CM, Baughcum AE, Specker BL. The relationship of childhood adiposity to parent body mass index and eating behavior. Obes Res 2000;8:234-240.

[5] Smith GD, Steer C, Leary S, Ness A. Is there an intrauterine influence on obesity? Evidence from parent child associations in the Avon Longitudinal Study of Parents and Children (ALSPAC). Arch Dis Child 2007;92:876-880.

[6] Gale CR, Javaid MK, Robinson SM, Law CM, Godfrey KM, Cooper C. Maternal size in pregnancy and body composition in children. J Clin Endocrinol Metab 2007;92:3904-3911.

[7] Heude B, Kettaneh A, Rakotovao R, Bresson JL, Borys JM, Ducimetière P, Charles MA. Anthropometric relationships between parents and children throughout childhood: the Fleurbaix-Laventie Ville Santé Study. Int J Obes (Lond) 2005;29:12221229. 
[8] Blair PS, Drewett RF, Emmett PM, Ness A, Emond AM. Family, socioeconomic and prenatal factors associated with failure to thrive in the Avon Longitudinal Study of Parents and Children (ALSPAC). Int J Epidemiol 2004;33:839-847.

[9] Griffiths LJ, Dezateux C, Cole TJ. Differential parental weight and height contributions to offspring birthweight and weight gain in infancy. Int J Epidemiol 2007;36:104-107.

[10] Maillard G, Charles MA, Lafay L, Thibult N, Vray M, Borys JM, Basdevant A, Eschwège E, Romon M. Macronutrient energy intake and adiposity in non obese prepubertal children aged 5-11 y (the Fleurbaix Laventie Ville Santé Study). Int J Obes Relat Metab Disord 2000;24:1608-1617.

[11] Berkey CS. Comparison of two longitudinal growth models for preschool children. Biometrics 1982;38:221-234.

[12] Magnus P, Gjessing HK, Skrondal A, Skjaerven R. Paternal contribution to birth weight. J Epidemiol Community Health 2001;55:873-877.

[13] Safer DL, Agras WS, Bryson S, Hammer LD. Early body mass index and other anthropometric relationships between parents and children. Int J Obes Relat Metab Disord 2001;25:1532-1536.

[14] Harvey NC, Poole JR, Javaid MK, Dennison EM, Robinson S, Inskip HM, Godfrey KM, Cooper C, Sayer AA, Group SWSS. Parental determinants of neonatal body composition. J Clin Endocrinol Metab 2007;92:523-526.

[15] Palmert MR, Hirschhorn JN. Genetic approaches to stature, pubertal timing, and other complex traits. Mol Genet Metab 2003;80:1-10.

[16] Silventoinen K, Sammalisto S, Perola M, Boomsma DI, Cornes BK, Davis C, Dunkel L, Lange MD, Harris JR, Hjelmborg JVB, Luciano M, Martin NG, Mortensen 
J, Nisticò L, Pedersen NL, Skytthe A, Spector TD, Stazi MA, Willemsen G, Kaprio J. Heritability of adult body height: a comparative study of twin cohorts in eight countries. Twin Res 2003;6:399-408.

[17] van Dommelen P, de Gunst MCM, van der Vaart AW, Boomsma DI. Genetic study of the height and weight process during infancy. Twin Res 2004;7:607-616.

[18] Veldhuis JD, Roemmich JN, Richmond EJ, Rogol AD, Lovejoy JC, SheffieldMoore M, Mauras N, Bowers CY. Endocrine control of body composition in infancy, childhood, and puberty. Endocr Rev 2005;26:114-146.

[19] O'Dell SD, Day IN. Insulin-like growth factor II (IGF-II). Int J Biochem Cell Biol 1998;30:767-771.

[20] Haig D. Evolution in Health and Medicine Sackler Colloquium: Transfers and transitions: Parent-offspring conflict, genomic imprinting, and the evolution of human life history. Proc Natl Acad Sci USA 2009.

[21] Estourgie-van Burk GF, Bartels M, van Beijsterveldt TCEM, Delemarre-van de Waal HA, Boomsma DI. Body size in five-year-old twins: heritability and comparison to singleton standards. Twin Res Hum Genet 2006;9:646-655. Heude B, Ong KK, Luben R, Wareham NJ, Sandhu MS. Study of association between common variation in the insulin-like growth factor 2 gene and indices of obesity and body size in middle-aged men and women. J Clin Endocrinol Metab 2007;92:2734-2738.

[23] Ong KK, Petry CJ, Barratt BJ, Ring S, Cordell HJ, Wingate DL, Pembrey ME, Todd JA, Dunger DB. Maternal-fetal interactions and birth order influence insulin variable number of tandem repeats allele class associations with head size at birth and childhood weight gain. Diabetes 2004;53:1128-1133. 
Evidence of genetic regulation of fetal longitudinal growth. Early Hum Dev 2005;81:823-831.

[25] Vella A, Bouatia-Naji N, Heude B, Cooper JD, Lowe CE, Petry C, Ring SM, Dunger DB, Todd JA, Ong KK. Association analysis of the IGF1 gene with childhood growth, IGF-1 concentrations and type 1 diabetes. Diabetologia 2008;51:811-815.

[26] Stunkard AJ, Berkowitz RI, Schoeller D, Maislin G, Stallings VA. Predictors of body size in the first $2 \mathrm{y}$ of life: a high-risk study of human obesity. Int J Obes Relat Metab Disord 2004;28:503-513.

[27] Fulkerson JA, McGuire MT, Neumark-Sztainer D, Story M, French SA, Perry CL. Weight-related attitudes and behaviors of adolescent boys and girls who are encouraged to diet by their mothers. Int J Obes Relat Metab Disord 2002;26:15791587

[28] Benton D. Role of parents in the determination of the food preferences of children and the development of obesity. Int J Obes Relat Metab Disord 2004;28:858869. 
Parents' and offspring's characteristics (mean \pm SD or geometric mean $[95 \%$ CI]

\begin{tabular}{|c|c|c|c|}
\hline Parents $^{\text {a }}$ & Fathers & Mothers & \\
\hline $\mathrm{N}$ & 162 & 162 & \\
\hline Age (y) & $43.8 \pm 4.9$ & $41.8 \pm 4.4$ & \\
\hline Weight (kg) & $80.3 \pm 12.0$ & $64.6 \pm 11.8$ & \\
\hline Height (m) & $1.76 \pm 0.04$ & $1.63 \pm 0.06$ & \\
\hline BMI $\left(\mathrm{kg} / \mathrm{m}^{2}\right)^{\mathrm{b}}$ & $25.6[19.7-33.2]$ & $23.8[17.2-33.1]$ & \\
\hline Offspring $^{c}$ & Boys & Girls & $\mathrm{p}$ \\
\hline $\mathrm{N}=235$ & 122 & 113 & 0.56 \\
\hline Gestational age (wk) & $38.7 \pm 1.9$ & $39.0 \pm 1.6$ & 0.52 \\
\hline Birth weight $(\mathrm{kg})$ & $3.39 \pm 0.53$ & $3.35 \pm 0.52$ & 0.14 \\
\hline Birth length $(\mathrm{cm})$ & $50.3 \pm 2.3$ & $49.7 \pm 2.2$ & 0.003 \\
\hline Birth ponderal index $\left(\mathrm{kg} / \mathrm{m}^{3}\right)$ & $26.4 \pm 2.6$ & $27.1 \pm 2.5$ & 0.07 \\
\hline Weight $(\mathrm{kg})$ at 9 months & $8.92 \pm 1.0$ & $8.55 \pm 1.0$ & 0.0003 \\
\hline Height $(\mathrm{cm})$ at 9 months & $72.1 \pm 2.7$ & $70.7 \pm 3.0$ & $<0.0001$ \\
\hline BMI $\left(\mathrm{kg} / \mathrm{m}^{2}\right)$ at 9 months & $17.2 \pm 1.6$ & $17.1 \pm 1.7$ & 0.46 \\
\hline Weight $(\mathrm{kg})$ at 2 years & $12.6 \pm 1.7$ & $12.1 \pm 1.4$ & 0.001 \\
\hline Height $(\mathrm{cm})$ at 2 years & $87.6 \pm 3.4$ & $86.0 \pm 3.3$ & 0.0003 \\
\hline BMI $\left(\mathrm{kg} / \mathrm{m}^{2}\right)$ at 2 years & $16.4 \pm 1.8$ & $16.3 \pm 1.4$ & 0.46 \\
\hline Age (years) at last examination & $10.3 \pm 1.4$ & $10.3 \pm 1.3$ & 0.96 \\
\hline Weight $(\mathrm{kg})$ at last examination & $34.1 \pm 8.2$ & $34.8 \pm 8.6$ & 0.49 \\
\hline Height $(\mathrm{cm})$ at last examination & $141.8 \pm 9.6$ & $141.8 \pm 10.9$ & 0.99 \\
\hline BMI $\left(\mathrm{kg} / \mathrm{m}^{2}\right)$ at last examination & $16.7 \pm 2.6$ & $17.0 \pm 2.6$ & 0.35 \\
\hline
\end{tabular}

a All differences between parents highly significant $(\mathrm{p}<0.0001)$ by paired comparisons

b Geometric mean $[95 \% \mathrm{CI}]$

c Comparisons between boys and girls adjusting for family 


\section{FIGURES}

1A

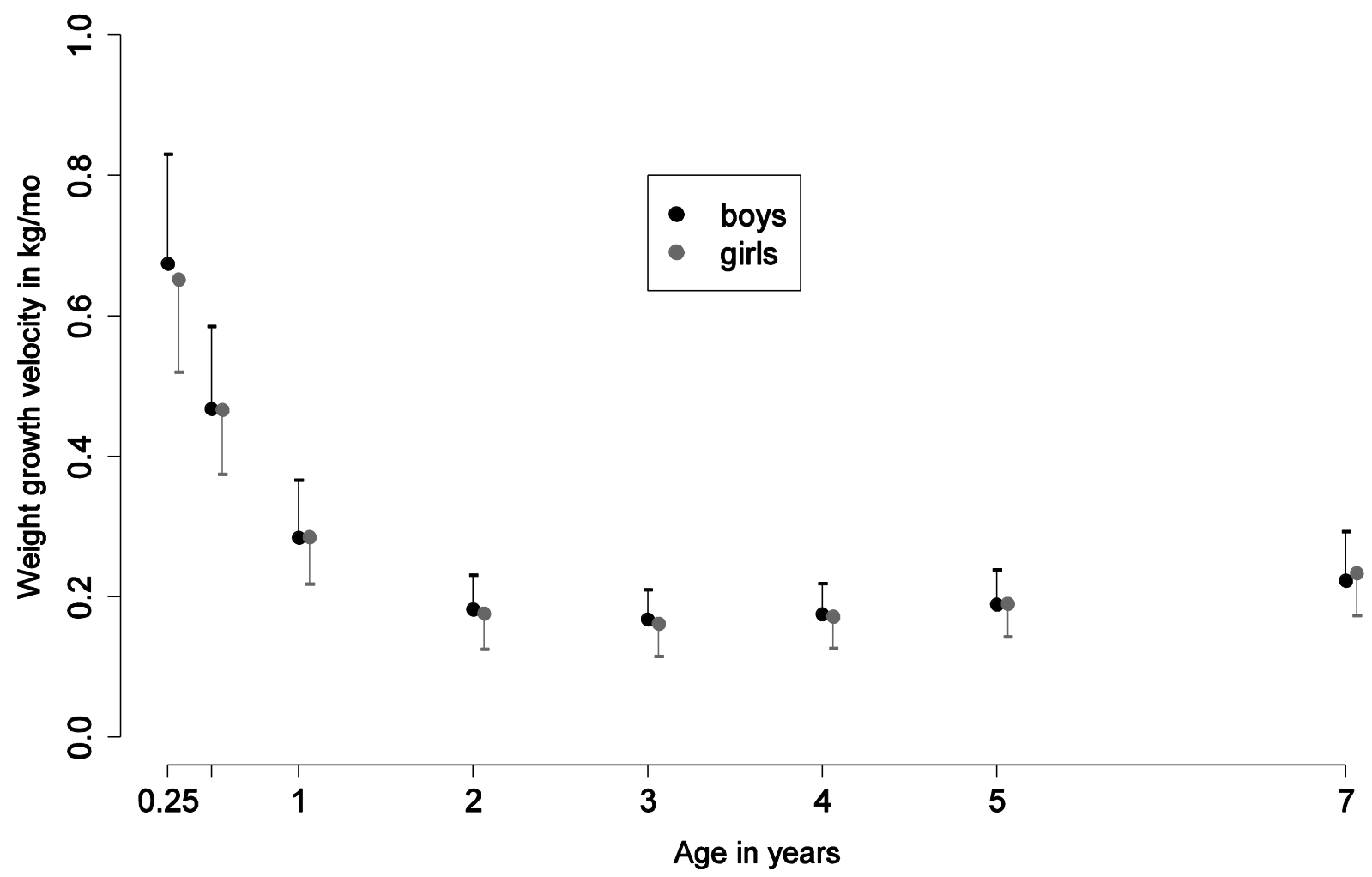

1B

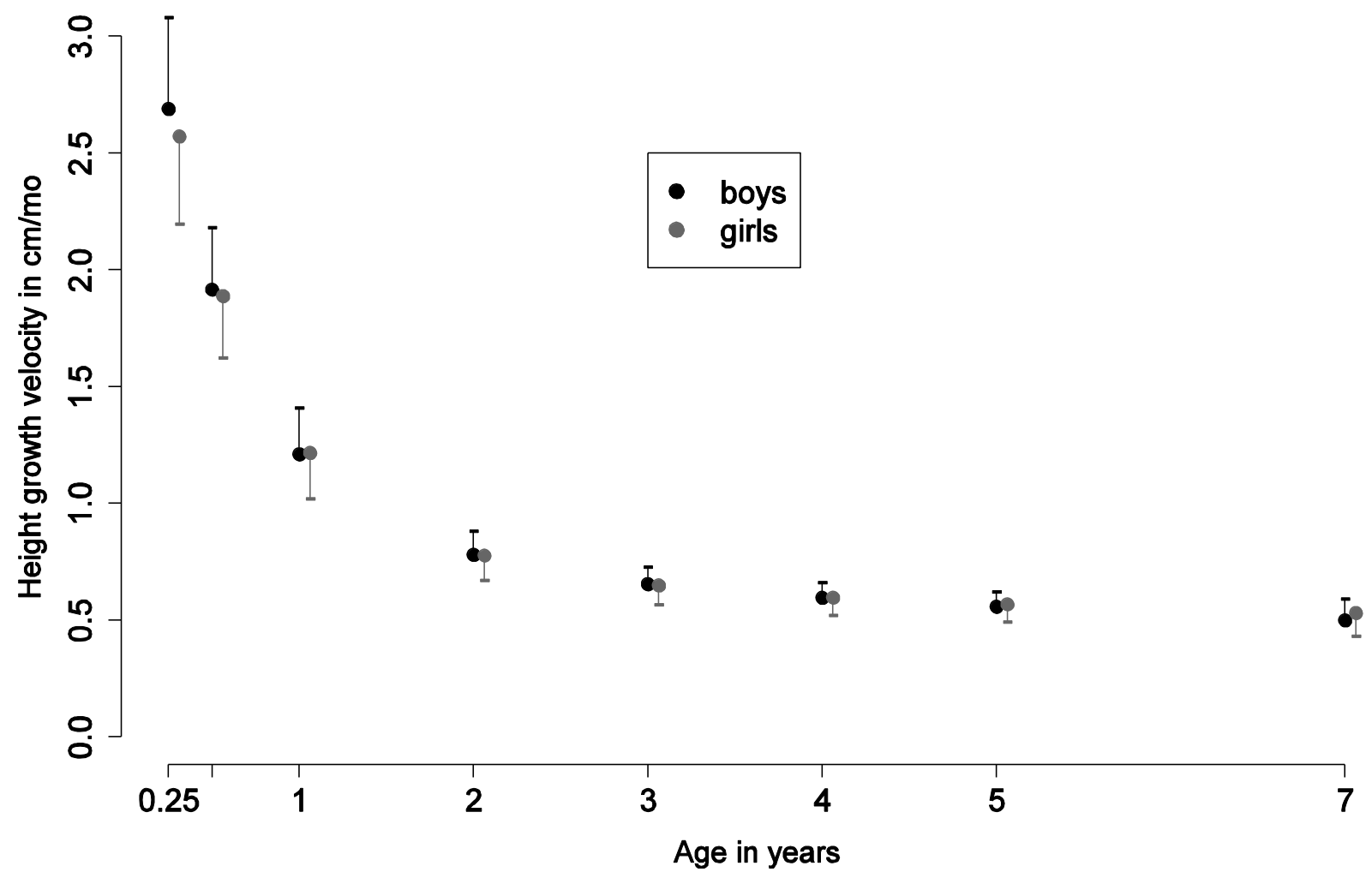


2A

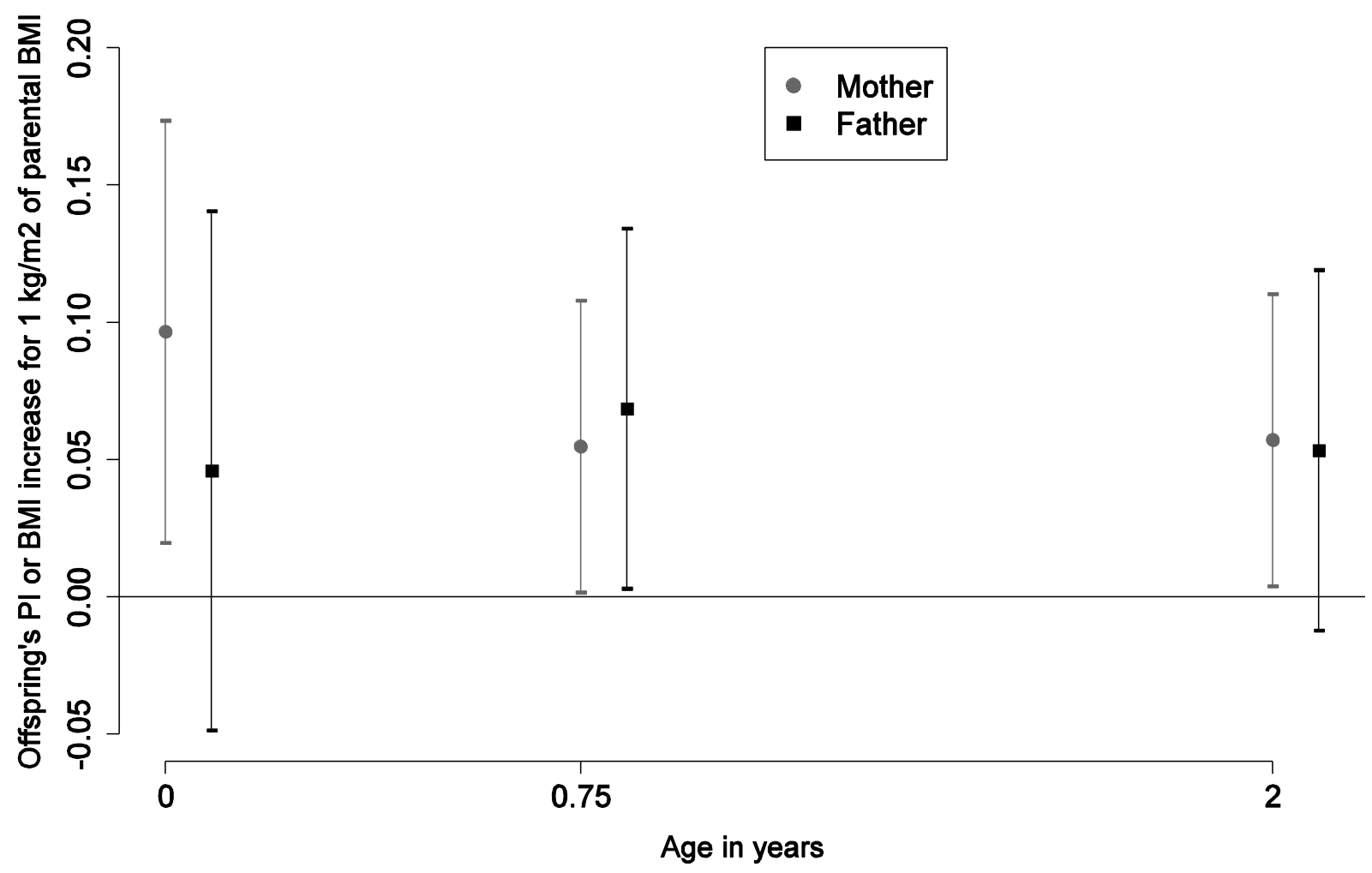

2B

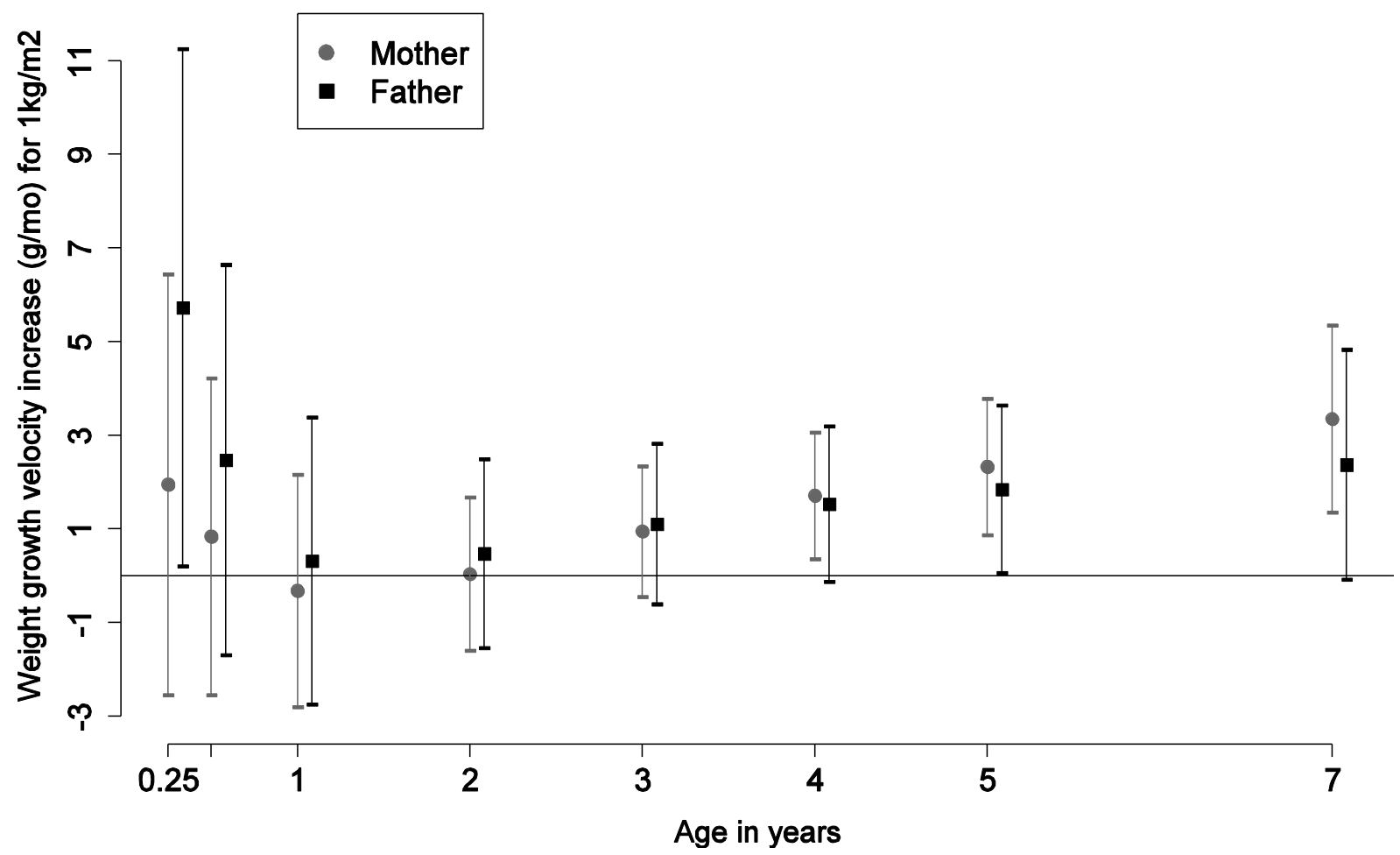


3A

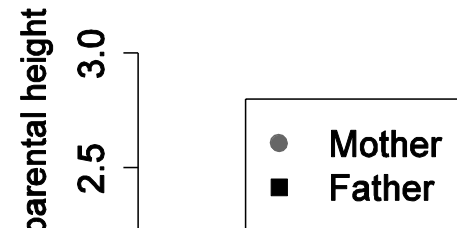

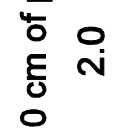

으

흔

हैํํ
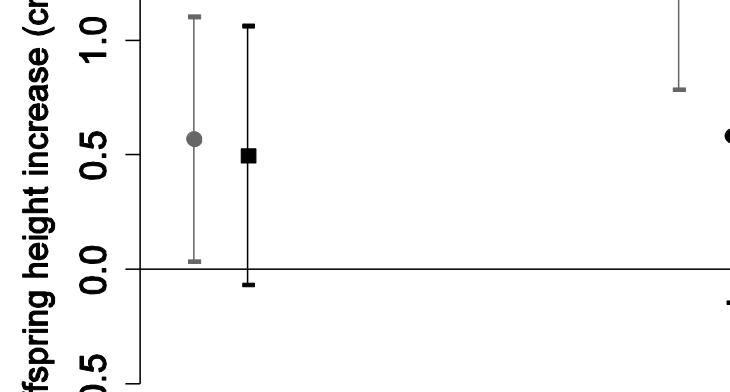

竞

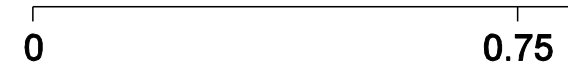

Age in years

3B

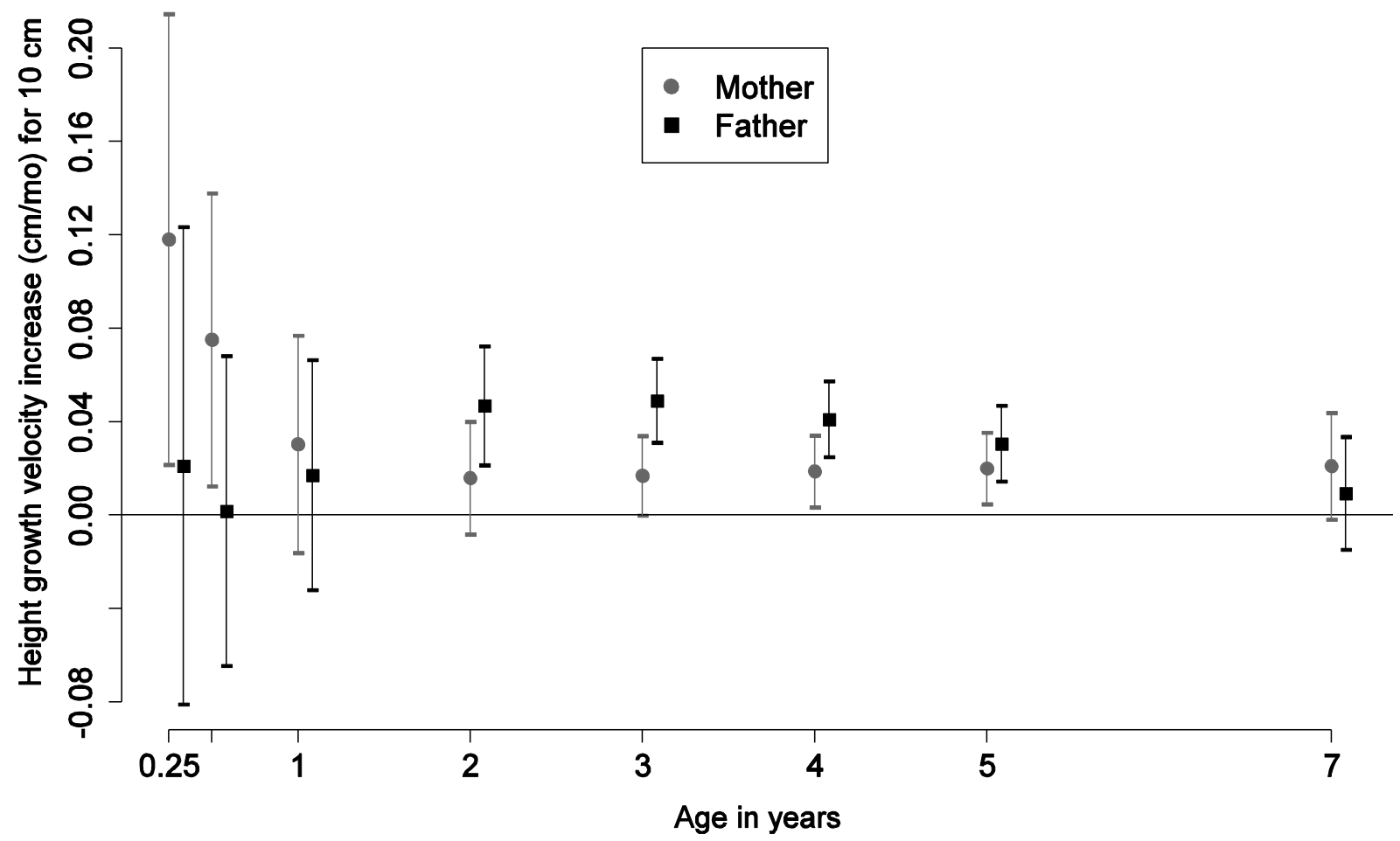




\section{SUPPLEMENTARY FIGURES}

S1A: Same legend as Figure 2B in boys

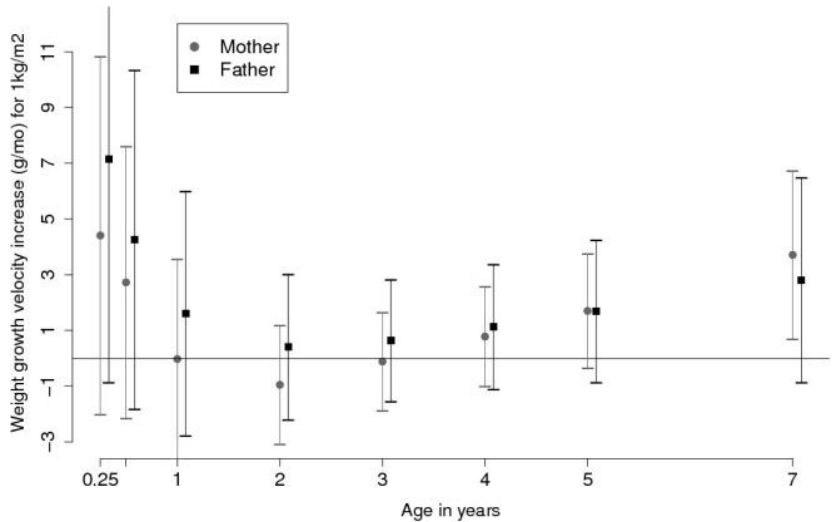

S2A: Same legend as Figure 3B in boys

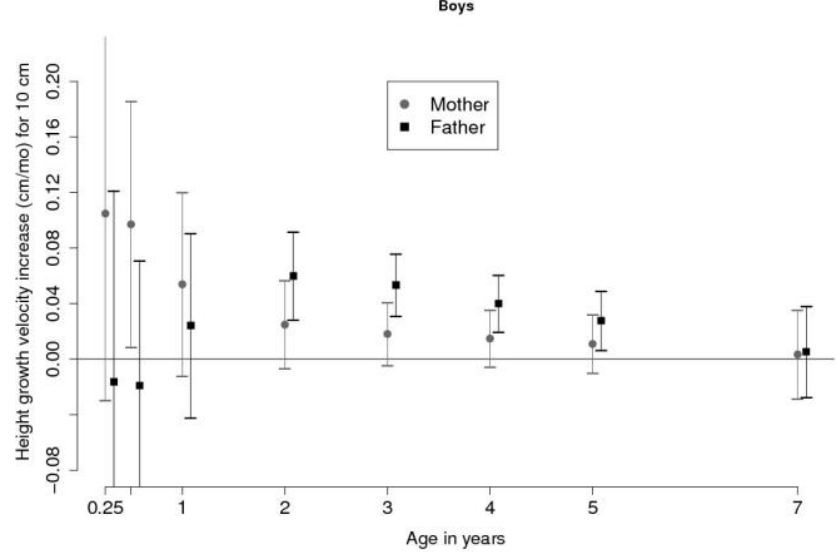

S1B: Same legend as Figure 2B in girls

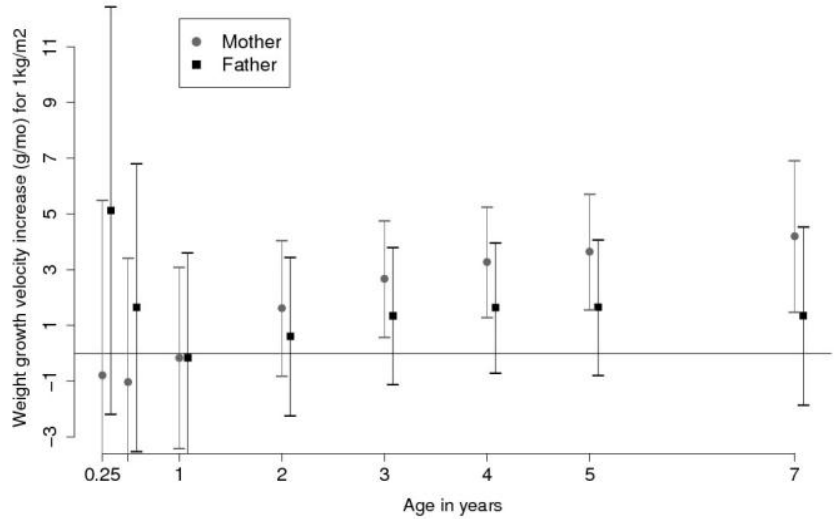

S2B: Same legend as Figure 3B in girls

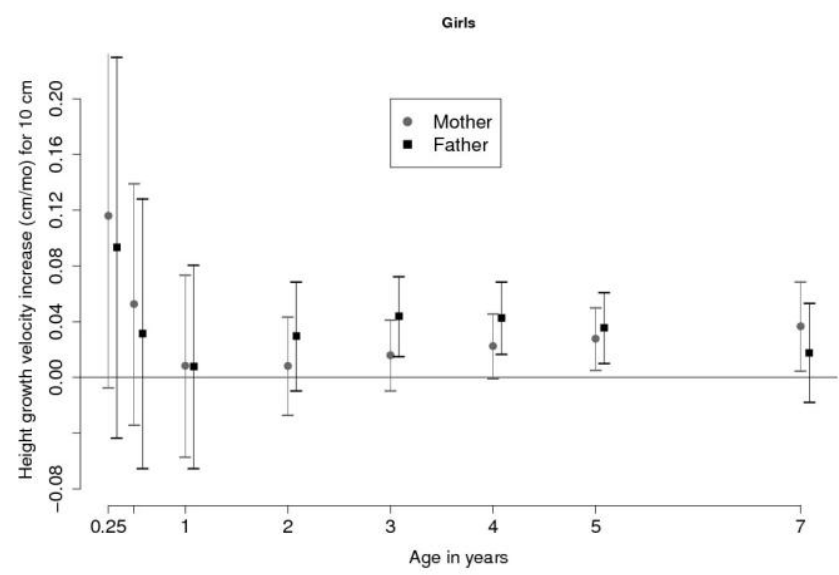

